\title{
Hazardous hydrogeological processes in deep road trenching on the section of the Khekhtsir ridge
}

\author{
Sergey Kvashuk ${ }^{1, *}$, Valerii Kulakov ${ }^{2}$, and Stanislav Gilmutdinov ${ }^{1}$ \\ ${ }^{1}$ Far Eastern State Transport University, 47 Serysheva St., Khabarovsk, 680021, Russia \\ ${ }^{2}$ Institute of water and ecological problems of FEB RAS, 56 Dikopoltceva St., Khabarovsk, 680000, \\ Russia
}

\begin{abstract}
During the construction of the motorway bypass of Khabarovsk on the northern outskirts of the Khekhtsir block rise, composed of strongly dislocated Mesozoic and Paleozoic rocks, on the section of the Khekhtsir ridge watershed crossing in deep road trenching of rock formations, dangerous hydrogeological manifestations, threatening the normal construction and operation of the road, were revealed. By the special tests (well drilling, geophysical studies using the VES survey method, hydrometric measurements of the groundwater discharges in excavated cuvettes and wells slug-out test), it is determined that the hydrogeological conditions of the site are very complex, as the groundwater supply area is located in the watershed part of the Khekhtsir Range that is crossed by the road. According to the specific electrical resistance test in the upper part of the massive and to the depth of the geological section low resistances blocks corresponding to the fragmented rocks and watered zone were fixed.
\end{abstract}

\section{Introduction}

The object of research is a deep road through cut on the constructed motorway from Khabarovsk to Vladivostok (Fig. 1). Dangerous hydrogeological manifestations arose during its construction: small fountains (griffins) of underground water were fixed from the west cut slope and through not pavement covered roadbed in summer, and underground water ice covers were formed on the western slope during winter time. Also, there were outcrops of groundwater at the base of the cut slopes on the left and right sides (Fig. 1). These phenomena would inevitably cause engineering and geological processes threatening reliable and safe operation of the road - active erosion, shedding of slopes, deformation of the base of the pavement. In these conditions, additional to the pre-project geotechnical and hydrogeological studies that were performed before excavation investigations were needed.

The objectives of the study were to identify the features of the engineering and geological conditions of the site operation and to assess its complexity, to identify the features of the geological section, to assess the areas of feeding and discharge of groundwater, to assess water flows and develop measures for dewatering.

\footnotetext{
*Corresponding author: s_kvashuk@mail.ru
} 


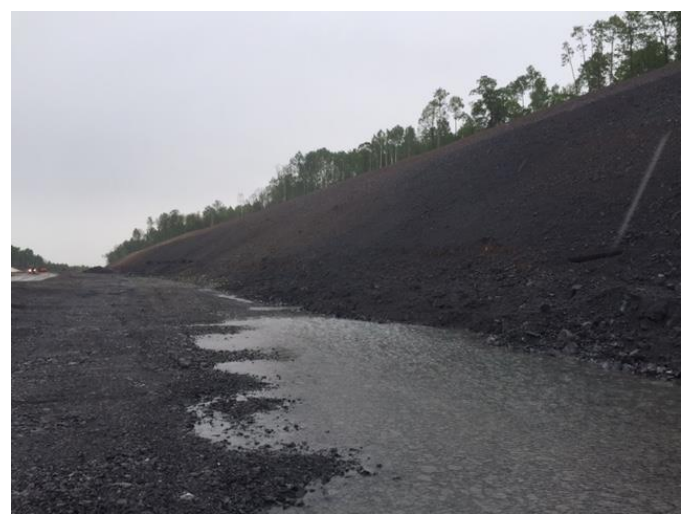

Fig. 1. Watered area at the cut slope bottom.

The research materials were obtained on the basis of complex field and analytical works, including hydrogeological and engineering geological reconnaissance routes, geophysical surveys by the VES method, assessment of water inflows by the method of water level restoration in wells, determination of the filtration coefficient, measurements of creek flow rates, formed by the spillage of groundwaters at the base of cut slopes, analytical calculations, analysis of published and stock materials.

\section{Study results}

Geologically, the study area is confined to the northern edge of Khekhtsir block raising folded strongly dislocated Mesozoic and Paleozoic rocks. [1]

The site of exploration refers to the Sikhote-Alin fold system, the West Sikhote-Alin structural-formation zone according to the tectonic zoning.

The Khekhtsir rift stretches out onto the day surface through the exploration area in the north-western direction and crosses the motorway. The fault in the rocks is blocked by younger, loose detrital formations and is opened in the sides of the cut.

At the stage of the investigation of borehole \#9 loam was uncovered to a depth of $24.0 \mathrm{~m}$ in the dangerous area, at the points of the outflow of griffins, and rocky ground was not encountered.

This is probably the zone of fault, filled with clay soils with large clastic inclusions and coarse clastic soils. During the survey, the depressions of underground water were encountered in wells \#\# 10, 7 and 8.

According to geophysical survey conducted at the site of the recess, in step researches that was done by VES method the electrical resistance of soil increases with depth, indicating that there occur more durable monolithic rocky soils.

For example, VEZ-25 at a depth of $20.6 \mathrm{~m}$ showed an increase in resistance from 51 up to 1249 Ohm*m. VES-9 and VES-26 from depths of 45.1 and $45.0 \mathrm{~m}$ showed resistance increase up to 688.6 and $1736 \mathrm{Ohm}^{*} \mathrm{~m}$, respectively.

The geological section of the site is composed by eluvial-deluvial deposits - clays, loam, sandy loam, including gussets.

Roof of rock and semicate soils, opened at a depth of $0.9-20.0 \mathrm{~m}$, from the day surface of the natural relief. They are represented by clay shales, sandstones, durable, low and medium strength andesite, siliceous shales, alevrosandstones, siltstone, sandstone, lowstrength and intermediate strength grandiorites. Engineering and geological conditions of the site should be characterized as very complex in connection with the presence of the zone of fault. 
During the processing of geophysical studies, three zones were identified.

In the zone of low resistance value of the parameter of the electric resistivity of soil are 200-300 Ohm*m, that correspond to watery and fractured zone in the upper part and the whole depth of geotechnical incision.

The mid-range zone corresponds to the transitional fractured part of the rock soil in the fault zone with a resistance of $350-600 \mathrm{Ohm} * \mathrm{~m}$. Ferrugination is fixed through the cracks or they are filled with clay, which also confirms the presence of a fault zone.

High-resistance zone with electrical resistance of rocks from 650 to $1000 \mathrm{Ohm}^{*} \mathrm{~m}$ characterizes the presence of monolithic weakly fractured rocks in the geological section. The results of geophysical studies received by the VES method were confirmed by drilling wells and at the opening (penetration) of the cut.

Hydrogeological observations within the cut revealed that the yield of underground fissured veins is explained by the presence of a fault fixed in the rock. Unlike groundwater discharge in Kuznetsovsky tunnel, traversed on Sikhote-Alin [2], where it was established that the movement of groundwater through the vadose zone is vertically-downward within the array of fractured rocks, the investigating area is characterized by recesses observed upward-thrusting fractured gangue water movement.

A considerable amount of ice was formed on the west cut slope during excavation in the winter periods 2014-2015 and 2015-2016. Underground water poured out through the strewn roadway in the western ditch and frosts formed in the winter of $2016-2017$. According to the builders, the flowing water was "warm" (about $8-12^{\circ} \mathrm{C}$ ) compared to the ice water that appears when snow and ice melt. Also there are griffins in places of standing of water in a ditch. The water flow along the western cuvette is directed to the south.

During hydrogeological survey of the road on the watershed portion of the recess the measurements of groundwater discharge flow was done with floats in cells - two in the west and one - in the east.

The measured discharge of groundwater in the south of the route along the western cuvette from the first to the second metering area increased from 13 to $141 / \mathrm{sec}$, i.e. it reached 46.8 - $50.4 \mathrm{~m}^{3} /$ hour $\left(1123-1210 \mathrm{~m}^{3} /\right.$ day $)$. Then the flow along the western cuvette disappeared in the stone loading of the cuvette or under the track of the route, and $150-200 \mathrm{~m}$ reappeared in the eastern cuvette. Here, groundwater consumption was $81 / \mathrm{sec}\left(28 \mathrm{~m}^{3} /\right.$ hour or $691 \mathrm{~m}^{3} /$ day).

If such fixed water inflows are maintained (about $50 \mathrm{~m}^{3} /$ hour), without taking into account the underground flow under the roadway, the possible minimum volume of accumulated ice can reach a volume of the order of $140,000 \mathrm{~m}^{3}$ during the winter period from December to March. Part of the outflowing pressurized groundwater is likely to freeze under the track, causing the graveled soils at the base of the roadway to be frost heaved.

To assess the value of the rock hydraulic conductivity in the base of the motorway, two wells (\#14 and \#15) of $150 \mathrm{~mm}$ diameter were drilled with a pneumatic impact method, with vacuum extraction of drilled rock and groundwater $10.5 \mathrm{~m}$ deep. After completion of the drilling, groundwater level restoration measurement was done.

Well \#14 opened the water-saturated layer at the base of the road bed to a depth of about 2.5 - $3.9 \mathrm{~m}$. Well \#15 appeared to have uncovered weakly fractured rocks and no water inflow from near-surface layers was observed.

According to the available values of the hydraulic conductivity for each well, depending on the time from the beginning of the observations of the level restoration, the calculated value of the hydraulic conductivity is determined as close to a constant [3].

Using the experience of studying the groundwater discharge in the area of Tynda $[4,5]$, where the total amount of groundwater resources exceeded the recorded in ice covers at 4-6 times, it can be assumed that the total ground water discharge on the highway under construction on $800 \mathrm{~m} \mathrm{leg}$, can reach $200-250 \mathrm{~m}^{3} /$ hour (up to $6000 \mathrm{~m}^{3} / \mathrm{day}$ ). The research 
materials were obtained on the basis of complex field and analytical works, including hydrogeological and engineering geological reconnaissance routes, geophysical surveys fulfilled by the VES method, assessment of water inflows by the method of level restoration in wells, determination of the filtration coefficient, measurements of creek flow rates, spillage of groundwaters in base of the seizure, analytical calculations, analysis of published and stock materials.

\section{Interpretation of results}

Partial stood waterlogging area was observed before opening of the recess in the southern part of the future highway having appreciable slope surface to south. This evidence of constant surface wetting in slope is due to discharge of pressure fracture-vein groundwater through fault zone and is not associated with seasonal moistening of deluvial deposits.

Groundwater wells at the site were opened while drilling geotechnical wells \#\# 4, 7, 8 and 10. Spouting groundwater was recorded in the wells \#\# 8,10 and 12. Unfortunately, there is no fixed groundwater pressurized level.

Collected data, together with geophysical studies performed by VES method, indicate very complex structure of the mountain soil body under constructed highway with constant unloading of pressurized fractured-veined groundwater over individual high-permeability cracks in the zone of steeply declining fault, which is composed of detrital material with clay aggregate and rock blocks. These unloading places are located under the wearing course of the motorway on a $600 \mathrm{~m}$ stretch.

Areas of elevated hypsometric marks terrain to the west and south-west within Khekhtsir ridge are recharge are for aquifer fracture-vein waters.

Based on the results of analysis of the materials of the conducted studies and stock materials, for the well \#14 the calculated value of the hydraulic conductivity can be taken equal to $2.0 \mathrm{~m} /$ day, and for well \#2 - $0.2 \mathrm{~m} /$ day.

According to the results of ground geophysical works performed by the VES method and hydrogeological study of the section of the route on the pass in the cut, it is established that there is a steeply fault represented by a zone of crushed rocks with increased water permeability. Pressure fissure-veined water circulates inside the soil body and that is confirmed by recordings of water discharge during the excavation of the cut, by the appearance of ice during the winter periods on the western slope and by the constant flow of groundwater in summer.

Unloading of fissure-veined water flowing into the base of the road under construction was observed in May-June of 2017. According to the data collected from the well \#14, the groundwater level at the end of the restoration monitoring process was at a depth of $0.57 \mathrm{~m}$ from the road surface.

The permeability of the soil is extremely heterogeneous in the zone of fault. The hydraulic conductivity determined from the results of the restoration of groundwater level in the wells varies from 0.2 to $2.0 \mathrm{~m} /$ day.

Measured water flow at three points in the cuvettes of the route varied from 8 to $14 \mathrm{l} / \mathrm{s}$ (28.8 $-50.4 \mathrm{~m}^{3} /$ hour). The surface current on the site from metering point \#2 to \#3 disappears under the roadway in the direction from the western ditch to the eastern one.

If such water inflows are preserved $\left(50 \mathrm{~m}^{3} /\right.$ hour), the possible volume of accumulated glaciers can reach a volume of $140,000 \mathrm{~m}^{3}$ during the winter period from December to March. Part of the outflowing pressure crack-veined groundwater will freeze under the path, causing the punching of gravelly soils.

The total value of groundwater discharge (emerging on the surface and hidden in the destroyed rocky rocks) under the roadway can reach $200-250 \mathrm{~m}^{3} /$ hour (up to $6,000 \mathrm{~m}^{3} /$ day) on a $600 \mathrm{~m}$ long section $[4,5]$. 
The revealed features of the engineering-geological structure and hydrogeological conditions of the site and the predicted volume of groundwater discharge determine the ineffectiveness of dewatering by exclusively linear drainage usage, even double-sided. In our opinion, linear drainage should be supplemented with reservoir drainage to intercept groundwater draining under the roadway from the bottom of the cut (Fig. 2).

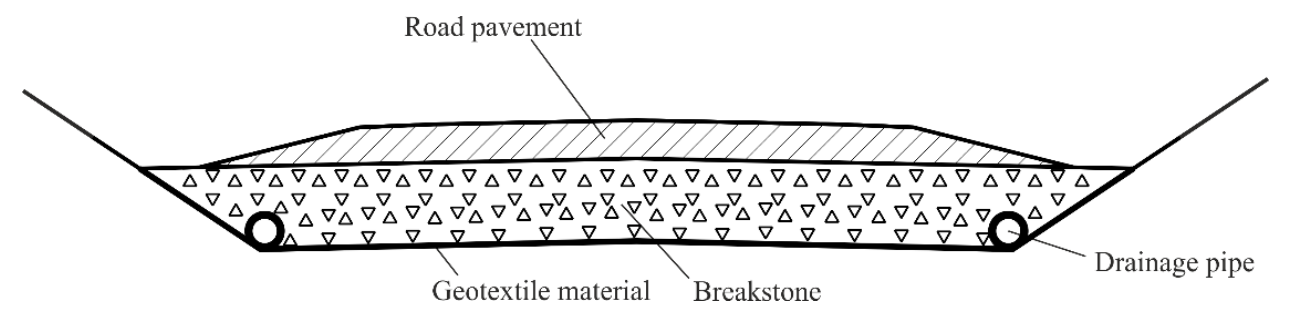

Fig. 2. The construction of drainage.

\section{Conclusions}

It should be noted that the need to build a drainage structure not specified in the project documentation will lead to a significant construction costs rise, and, possibly, will lead to delay the commissioning of the facility. Special attention should be paid to the fault $\mathrm{s}$ and the presence of swampy areas on elevated hypsometric marks in the future, while preparing the schedule of engineering and geological surveys. It is necessary to include systematic observations of the water temperature and the flow rates of the sources during the entire survey period when these features are combined. The presence of fissured veins while interpreting the results of surveys in such conditions cannot be excluded based mainly on the results of the VES, since at large depths of sensing the filtering zones are negligibly small in comparison with the sounded array. Good signs of the presence of fissured veins are the anomalies of the temperature regime and the constancy of the flow rate of the source over time.

\section{References}

1. N.A. Marinov, Gidrogeologiia SSSR. Khabarovskii krai i Amurskaia oblast' 23 (1971)

2. G.A. Zlobin, V.V. Kulakov, Water Resources 42-7, 876 - 888 (2015)

3. S.G. Simonchik, Spravochnoe posobie dlia obrabotki materialov inzhenernogeologicheskikh izyskanii (2005)

4. V.V. Kulakov, Mestorozhdeniia presnykh podzemnykh vod Priamur'ia (1990)

5. V.V. Kulakov, V.V. Sidorkin, Problemy naledevedeniia, 131 - 137 (1991) 